\title{
Dampak Mediasi Market-Driven Costing Terhadap Hubungan Intensitas Persaingan dan Karakteristik Pelanggan dengan Kinerja Keuangan
}

\author{
Bambang Tjahjadi ${ }^{1 *}$, Noorlailie Soewarno ${ }^{1}$ \\ ${ }^{1}$ Fakultas Ekonomi dan Bisnis, Universitas Airlangga \\ Jl. Airlangga 4-6, Surabaya 60286 \\ *Penulis korespondensi; email: bambangtjahjadi@gmail.com
}

\begin{abstract}
ABSTRAK
Kinerja keuangan organisasi merupakan hal yang krusial bagi pemegang saham karena sebagian besar organisasi diharapkan menghasilkan laba agar dapat mendanai kebutuhan untuk pertumbuhan organisasi tersebut. Penelitian ini memfokuskan pada organisasi rumah sakit mengingat tren persaingan yang semakin tinggi antar rumah sakit di Surabaya. Sejumlah investor lokal dan asing telah berinvestasi secara agresif di sektor rumah sakit. Dalam era informasi, karakteristik kebutuhan pelanggan akan kesehatan juga menjadi dinamis. Pelanggan rumah sakit makin canggih, berpengetahuan kesehatan yang baik dan makin banyak tuntutan. Penelitian ini akan mengkaji secara empiris dampak market-driven costing terhadap hubungan-hubungan intensitas persaingan-karakteristik pelanggan-kinerja keuangan. Sebanyak tiga puluh sembilan manajer berpartisipasi dalam penelitian ini. Hasil-hasil penelitian menunjukkan bahwa; (1) market-driven costing memediasi secara sempurna hubungan intensitas persaingan dan kinerja keuangan dan (2) market-driven costing memediasi secara sempurna hubungan karakteristik pelanggan dan kinerja keuangan.
\end{abstract}

Kata kunci: Market-driven costing, karakteristik pelanggan, intensitas persaingan, kienrja keuangan.

\begin{abstract}
The financial performance of organizatios is crucial to stockholders since most organizations are expected to generate margin in order to finance its growth. This study focuses on hospital organization because competitive intensity among hospitals in Surabaya tends to be higher and higher. Some local and foreign investors have invested aggressively in hospital business. The characteristics of healthcare customers are also dynamic in nature because of the information era. Healthcare customers are more sophisticated, knowledgable, and demanded. This study empirically investigates the mediating effect of market-driven costing on competitive intensity-customer characteristics-financial performance relationships. Thirty nine managers participated in this study. Result of the study shows that (1) marketdriven costing fully mediates competitive intensity-financial performance relationship, and (2) market-driven costing fully mediates customer characteristics-financial performance relationship.
\end{abstract}

Keywords: Market-driven costing, customer characteristics, competitive intensity, financial performance.

\section{PENDAHULUAN}

Sejak 1948, sehat (health) didefinisikan oleh WHO (World Health Organization) sebagai "a state of complete physical, mental and social well-being and not merely the absence of disease or infirmity" (www.who.int/about/definition/en/print.html.).
Dengan demikian, kesehatan merupakan faktor yang sangat penting dalam menciptakan kesejahteraan masyarakat. Masyarakat yang sehat mampu memicu produktivitas ekonomi sebuah negara, sementara masyarakat yang sakit dapat berdampak buruk bagi perekonomian negara. 
Rumah Sakit memainkan peran kritis dalam rantai nilai layanan kesehatan masyarakat. Baik tidaknya layanan kesehatan masyarakat banyak tergantung pada kinerja rumah sakit sebagai ujung tombaknya. Meskipun organisasi rumah sakit dipandang sebagai organisasi yang berorientasi nirlaba (nonprofit-oriented), tidak berarti kinerja keuangan menjadi tidak penting. Peran aspek keuangan pada organisasi bagaikan darah pada tubuh manusia. Terganggunya kinerja keuangan rumah sakit dapat dipastikan bakal mengganggu kinerja layanan kesehatan yang diberikan.

Tarif layanan kesehatan sangat berpengaruh pada kinerja keuangan rumah sakit. Ketika layanan kesehatan sudah menjadi komoditas dalam artian sulit dibedakan satu dengan lainnya, maka market-driven price akan berlaku seketika itu juga. Pengguna layanan kesehatan akan memilih rumah sakit yang memberikan harga paling murah untuk jenis layanan yang sama. Era BPJS Kesehatan yang dimulai pada 1 Januari 2014 telah menimbulkan masalah sendiri bagi manajemen rumah sakit. Tarif Badan Pengelola Jaminan Sosial (BPJS)-Kesehatan yang bersifat bundled price membutuhkan perhitungan unit cost layanan kesehatan yang lebih rinci dan akurat. Di saat inilah, manajemen rumah sakit membutuhkan market-driven cost yang tepat. Kesalahan dalam menentukan market-driven cost dipastikan bakal menimbulkan kesulitan keuangan rumah sakit.

Persaingan antar Rumah Sakit di Indonesia bakal menjadi semakin ketat. Industri layanan kesehatan sudah dianggap sebagai ladang bisnis yang menarik bagi para investor besar baik dari dalam negeri maupun mancanegara. Investor besar dalam negeri yang telah masuk dalam bisnis rumah sakit meliputi Lippo Group, Sinar Mas Group, Sahid Group, Mayapada Group, Kalbe Group dan Ciputra Group. Pemain asing juga sudah begitu tertarik memasuki pasar layanan kesehatan di Indonesia untuk segmen masyarakat menengah atas dengan membawa brand image mereka yang kuat dan sejumlah dana investasi yang besar dari Singapura maupun Australia. Intensitas persaingan antar rumah sakit sudah bisa dipastikan akan menjadi semakin tajam dari hari ke hari. Intensitas persaingan inilah yang ditengarai sebagai pemicu kebutuhan marketdriven cost pada organisasi rumah sakit.

Karakteristik pelanggan juga ditengarai mampu memicu kebutuhan manajemen terhadap kebutuhan menerapkan market-driven costing. Hal ini disebabkan karena tingkat kecanggihan pelanggan (degree of customer sophistication), tingkat perubahan persyaratan (rate of change of requirements), dan pengetahuan tentang kebutuhan di masa depan (knowledge of future requirements) yang menjadi karakteristik pelanggan ditengarai memicu kebutuhan manajemen terhadap market-driven cost.

Motivasi penelitian ini adalah melanjutkan penelitian Cooper dan Slagmulder (1997). Kontribusi penelitian ini meliputi hal-hal sebagai berikut: (1) secara teori, penelitian ini memberikan kontribusi terhadap Contingency Theory melalui marketdriven costing sebagai faktor kontinjensi yang memediasi hubungan intensitas persaingan dan karakteristik pelanggan dengan kinerja keuangan; (2) secara empirik, penelitian ini memperluas penelitian sebelumnya yang masih bersifat eksplorasi dengan melakukan penelitian dengan model kausalitas dari pengaruh mediasi market-driven costing pada hubungan intensitas persaingan dan karakteristik pelanggan dengan kinerja keuangan; dan (3) bila penelitian sebelumnya dilakukan pada perusahaan manufaktur di Jepang, penelitian ini dilakukan pada jenis organisasi yang berbeda, yaitu organisasi pelayanan kesehatan atau rumah sakit di Surabaya.

Berdasarkan latar belakang yang telah dikemukakan sebelumnya, maka masalah penelitian dapat dirumuskan sebagai berikut: (a) apakah market-driven costing memediasi hubungan intensitas persaingan dengan kinerja keuangan?; dan (b) apakah market-driven costing memediasi hubungan karakteristik pelanggan dengan kinerja keuangan?. Dengan demikian, penelitian ini bertujuan untuk: (a) membuktikan pengaruh mediasi market-driven costing terhadap hubungan intensitas persaingan dengan kinerja keuangan; dan (b) membuktikan pengaruh mediasi market-driven costing terhadap hubungan karakteristik pelanggan dengan kinerja keuangan.

\section{Intensitas Persaingan, Market-Driven Costing dan Kinerja Keuangan}

Era globalisasi dan era informasi telah mengakibatkan lingkungan bisnis berubah secara dinamis (Ireland et al., 2013). Lingkungan bisnis eksternal meliputi lingkungan ekonomi, sosial budaya, politik, hukum, dan teknologi telah berdampak pada lingkungan industri dan lingkungan internal organisasi. Menurut Porter (1980), perubahan lingkungan industri mencakup 5 (lima) kekuatan yang mengatur profitabilitas industri, yaitu: (1) kekuatan tawar pemasok, (2) kekuatan tawar pembeli, (3) ancaman pendatang baru, (4) keberadaan barang substitusi, dan (5) rivalitas pemain dalam industri.

Struktur industri sangat menentukan aturan main dalam bersaing maupun strategi yang 
digunakan oleh organisasi. Persaingan yang semakin dinamis dan tinggi intensitasnya menyebabkan para pesaing semakin sulit diidentifikasi maupun diantisipasi. Gatignon (1984) dan Weitz et al. (1986) mendefinisikan intensitas persaingan sebagai "the degree of rivalry among firms producing products that are close substitutes", yaitu tingkat persaingan di antara organisasi yang menghasilkan produk dengan substitusi yang dekat. Persaingan merupakan inti sukses atau gagalnya organisasi.

Intensitas persaingan sangat berpengaruh terhadap kinerja profitabilitas organisasi. Cool et al. (1995) menyatakan bahwa meningkatnya rivalitas persaingan menurunkan profitabilitas rerata industri. Tindakan dan respons masingmasing organisasi yang sedang bersaing dalam suatu industri bersifat mutually independent, dalam arti bahwa daya saing, strategi, dan tingkat pengembalian di atas rerata hanya bisa dicapai bila strategi tidak diimplementasi secara terisolasi dengan respons para pesaing (Baum dan Korn, 1999; Henderson dan Mitchell, 1997). Oleh karena itu, organisasi perlu memperhatikan dinamika dan intensitas persaingan dalam industrinya.

Baik atau buruknya kinerja keuangan sebuah organisasi dapat diketahui dengan membandingkan dengan rerata kinerja industri di mana organisasi beroperasi. Organisasi yang memiliki keunggulan bersaing (competitive advantage) tinggi akan mampu mendapatkan tingkat pengembalian di atas rata-rata industri (aboveaverage return $/ A A R$ ). Kinerja keuangan merupakan kinerja dalam perspektif pemegang saham atau investor yang menurut Kaplan dan Norton (2004) terdiri dari kinerja sebagai hasil dari implementasi strategi pertumbuhan (growth strategy) dan strategi produktivitas (productivity strategy). Indikator-indikator kinerja keuangan umumnya dikembangkan dari sasaran-sasaran strategis organisasi yang meliputi struktur biaya, utilisasi aset, pertumbuhan pendapatan, dan pertumbuhan kemampulabaan

Mowen et al. (2014) menyatakan bahwa target costing merupakan metode untuk menentukan biaya produk atau jasa yang didasarkan pada tingkat harga (target price) yang pelanggan mau membayar. Pemanfaatan target costing dalam praktik manajemen biaya boleh dikatakan sudah lama dilakukan. Semakin tingginya intensitas persaingan bisnis membuat konsep target costing ini menjadi semakin menarik untuk diimplementasikan organisasi dalam mengelola product life cycleCooper dan Slagmulder (1997) menyatakan bahwa "The target costing process at most firms can be broken into three major steps. The first consists of market-driven costing, the second of productleveltarget costing, and the third of component-level target costing".
Sebenarnya, konsep target costing ini bukanlah konsep yang baru. Keberadaannya sudah dikenal sejak tahun 1960an dan diimplementasikan di Amerika Serikat oleh Ford (Shank, 1995) maupun di Jepang oleh Toyota (Cooper and Tanaka, 1996). Dalam implementasi target costing, dikenal konsep market-driven costing. Cooper dan Slagmulder (1995) menyatakan bahwa marketdriven costing ini digunakan untuk mengubah tekanan-tekanan pasar akibat persaingan pada perancang produk dalam organisasi sekaligus para pemasok. Tingkat persaingan dicerminkan dengan mengurangkan target profit margin (tingkat margin yang diinginkan organisasi) terhadap target price (harga yang dianggap kompetitif di pasar) sehingga didapatkan target allowable cost (unit product cost yang seharusnya).

Setiap organisasi dituntut untuk memiliki kinerja keuangan yang baik. Tanpa kinerja keuangan yang baik, organisasi tidak berjalan secara optimal. Kinerja keuangan senantiasa menjadi fokus dari investor atau pemilik, sehingga manajemen juga wajib menjalankan apa yang menjadi fokus dari investor tersebut.

Kinerja keuangan yang baik diperoleh dari kepiawaian manajemen dalam meningkatkan pendapatan sekaligus mengelola biaya secara efisien. Meningkatkan pendapatan berarti manajemen harus berorientasi pada pasar yang semakin dinamis dan intensitas persaingan yang cenderung semakin tinggi. Menghadapi situasi demikian, maka manajemen perlu memiliki strategi harga yang tepat sehingga kompetitif di pasar. Harga yang ditentukan dengan melihat ketatnya persaingan (target price) diperlukan manajemen untuk memenangkan persaingan. Hal ini berarti manajemen membutuhkan market-driven costing, yaitu perhitungan biaya berbasis pada harga pasar yang telah ditentukan tersebut

Semakin tinggi intensitas persaingan, maka semakin tinggi kebutuhan terhadap market-driven costing. Selanjutnya, semakin meningkat pengelolaan biaya berbasis pasar, maka diharapkan dapat meningkatkan kinerja keuangan pula. Berdasarkan uraian tersebut, maka dapat dirumuskan hipotesis penelitian sebagai berikut.

H1: Market-driven Costing memediasi hubungan Intensitas Persaingan dengan Kinerja Keuangan

\section{Karakteristik Pelanggan, Market-Driven Costing dan Kinerja Keuangan}

Menurut Cooper dan Slagmulder (1995), terdapat 3 (tiga) karakteristik pelanggan yang berdampak pada meningkatnya kebutuhan marketdriven costing, yaitu: 
(1) tingkat kecanggihan pelanggan (degree of customer sophistication)

(2) tingkat perubahan persyaratan (rate of change of requirements), dan

(3) pengetahuan tentang kebutuhan di masa depan (knowledge of future requirements)

Tingkat kecanggihan pelanggan akan menentukan seberapa baik pelanggan tersebut mendeteksi perbedaan-perbedaan harga, kualitas, dan fungsi dari beragam produk yang bersaing. Semakin tinggi kecanggihan pelanggan maka pelanggan semakin mampu menentukan perbedaan-perbedaan kecil yang selanjutnya semakin mudah beralih ke produk pesaing. Semakin canggih pelanggan akan mengakibatkan survival zone suatu produk menjadi semakin sempit dan berdampak pada kegagalan suatu produk yang diluncurkan di luar zona tersebut yang berakibat pada kinerja keuangan yang buruk. Di sinilah manajemen organisasi perlu melakukan analisis pelanggan secara mendalam, khususnya menentukan lokasi survival zone tersebut.

Tingkat perubahan persyaratan menunjukkan seberapa cepat lokasi survival zone tersebut berpindah dari waktu ke waktu. Dengan demikian, semakin cepat perpindahan lokasi tersebut maka akan semakin sulit organisasi memprediksi dan menentukan kapan produk akan diluncurkan. Hal ini berpotensi menimbulkan dampak buruk pada tingkat pengembalian investasi atas produk yang dikembangkan tersebut.

Pengetahuan tentang kebutuhan di masa depan juga dipandang sebagai hal penting dalam analisis pelanggan. Semakin tinggi pengetahuan pelanggan terhadap kebutuhan masa depan semakin bermanfaat bagi organisasi untuk percaya pada preferensi pelanggan dalam menentukan lokasi survival zone tersebut. Dengan demikian, organisasi lebih percaya diri melakukan investasi dalam pengembangan produk baru yang diyakini dapat meningkatkan pertumbuhan pendapatan di masa yang akan datang.

Pada persaingan yang semakin tajam, peran pelanggan sangatlah penting. Organisasi berebut pelanggan dengan beragam strategi, termasuk strategi harga. Pelanggan hanya mau membayar dengan harga lebih tinggi bila produk yang ditawarkan memiliki pembeda yang jelas dan benarbenar memberikan nilai. Semakin tinggi tingkat kecanggihan pelanggan akan menentukan seberapa baik pelanggan tersebut mendeteksi perbedaan-perbedaan harga, kualitas, dan fungsi dari beragam produk yang bersaing. Hal ini berarti semakin menuntut manajemen organisasi untuk mampu mengelola biaya sesuai dengan keinginan pasar (market-driven costing), tanpa mengorban- kan margin yang diinginkan. Dari uraian sebelumnya dapat dirumuskan hipotesis penelitian sebagai berikut:

H2: Market-driven Costing memediasi hubungan Karakteristik Pelanggan dengan Kinerja Keuangan

\section{METODE PENELITIAN}

\section{Rancangan Penelitian}

Penelitian ini dirancang dengan menggunakan metode kuantitatif. Metode kuantitatif difokuskan untuk menguji secara empirik: (1) pengaruh mediasi market-driven costing terhadap hubungan intensitas persaingan dan kinerja keuangan, dan (2) pengaruh mediasi marketdriven costing terhadap hubungan karakteristik pelanggan dengan kinerja keuangan.

Penelitian ini juga mengkonfirmasi temuan metode kuantitatif dengan metode kualitatif. Metode kualitatif ditujukan untuk menggali tentang mengapa dan bagaimana intensitas persaingan, karakteristik pelanggan, marketdriven costing mempengaruhi kinerja keuangan.

\section{Populasi dan Sampel}

Populasi penelitian ini adalah seluruh rumah sakit yang beroperasi di Surabaya yaitu sebanyak 51 rumah sakit. Responden penelitian ini adalah para manager rumah sakit yang memiliki pengetahuan untuk menjawab pertanyaan penelitian yang terdapat dalam kuesioner. Sebanyak 39 manager rumah sakit berpartisipasi dalam penelitian ini. Para manager tersebut diharapkan sudah bekerja selama minimal 3 tahun. Dengan berpengalaman selama 3 tahun, diharapkan manager yang menjadi responden atau informan sudah memiliki pemahaman yang mendalam tentang rumah sakit dan lingkungannya di Surabaya.

\section{Teknik Pengumpulan Data}

Data kuantitatif yang berkaitan dengan variabel-variabel intensitas persaingan, karakteristik pelanggan, market-driven costing, dan kinerja keuangan diperoleh melalui kuesioner. Kuesioner dikirimkan kepada 51 rumah sakit dan 39 kuesioner kembali dan siap dioleh. Response rate atas pengiriman kuesioner sebesar $76 \%$. Data kualitatif diperoleh melalui wawancara mendalam (in-depth interview) melalui telepon pada 7 (tujuh) informan yang berlatar belakang keuangan dan medis dan dilakukan secara semi-structured. 


\section{Definisi Operasional Variabel}

1. Intensitas persaingan

Intensitas Persaingan dalam penelitian ini adalah tingkat rivalitas antar rumah sakit yang diproksikan melalui persepsi manager terhadap banyaknya pesaing, pentarifan layanan kesehatan, jenis layanan kesehatan yang diluncurkan di pasar, kebutuhan inovasi layanan. Instrumen pengukuran data kuantitatif menggunakan skala Likert antara 1 sampai dengan 7 . Instrumen data kualitatif menggunakan semi-structured interview.

2. Karakteristik pelanggan

Karakteristik Pelanggan dalam penelitian ini adalah persepsi manager rumah sakit terhadap tingkat kecanggihan pelanggan, tingkat perubahan persyaratan produk, dan pengetahuan terhadap kebutuhan di masa mendatang. Instrumen pengukuran data kuantitatif menggunakan skala Likert antara 1 sampai dengan 7. Instrumen data kualitatif menggunakan semi-structured interview.

3. Market-Driven Costing

Market-driven costing dalam penelitian ini adalah persepsi manager terhadap kebutuhan menentukan target costing akibat tekanan persaingan di dalam pasar yang ditentukan dengan mengurangkan target margin terhadap target price. Instrumen pengukuran data kuantitatif dengan menggunakan skala Likert antara 1 sampai dengan 7 . Instrumen data kualitatif menggunakan semi-structured interview.

4. Kinerja keuangan

Kinerja Keuangan dalam penelitian ini adalah persepsi manager rumah sakit terhadap kinerjakinerja yang berkaitan dengan pengelolaan biaya, utilisasi aset, pertumbuhan pendapatan, dan pertumbuhan kemampulabaan. Instrumen pengukuran data kuantitatif menggunakan skala Likert antara 1 sampai dengan 7 . Instrumen data kualitatif menggunakan semistructured interview.

\section{Teknik Analisis}

Teknik analisis yang digunakan sebagai penelitian kuantitatif adalah Structural Equation Modeling-Partial Least Square (SEM-PLS). Teknik analisis ini digunakan karena fokus penelitian adalah menguji pengaruh mediasi market-driven costing terhadap hubungan intensitas persaingan dengan kinerja keuangan, dan pengaruh mediasi market-driven costing terhadap hubungan karakteristik pelanggan dengan kinerja keuangan.
Model SEM-PLS dipilih karena dipandang sesuai dengan karakter penelitian ini, khususnya: (1) model dapat diestimasi dengan ukuran sampel kecil (35-50); (2) tidak mensyaratkan distribusi data karena model ini bersifat non-parametrik); dan (3) model ini dapat bekerja pada skala metric maupun ordinal (Sholihin dan Ratmono, 2013). Sementara itu, teknik analisis yang digunakan sebagai penelitian kualitatif adalah analisis data model interaktif yang terdiri dari reduksi data, penyajian data, dan penarikan kesimpulan/ verifykasi sebagai suatu proses yang saling terjalin satu dengan lainnya (Miles \& Huberman, 1992).

\section{Model Penelitian}

Merujuk pada latar belakang dan tinjauan teoritis yang dibahas pada bab-bab sebelumnya, maka model penelitian dapat digambarkan pada Gambar 1.



Gambar 1. Model Penelitian

\section{HASIL PENELITIAN DAN PEMBAHASAN}

\section{Profil Responden dan Statistik Deskriptif}

Hasil penelitian menunjukkan bahwa pendidikan responden adalah S1 (25 orang atau 64\%), S2 (9 orang atau 23\%), dan S3 (5 orang atau 13\%). Responden yang berumur antara 40-50 tahun sebanyak 27 orang (69\%), dan sebanyak 12 orang (31\%) berusia di atas 50 tahun. Sebanyak 24 responden $(62 \%)$ berjenis kelamin laki-laki, dan sebanyak 15 responden (38\%) berjenis kelamin perempuan.

\section{Intensitas Persaingan (IP)}

Data variabel Intensitas Persaingan (IP) diperoleh dari kuesioner dengan 3 (tiga) butir pernyataan yang menggambarkan proksinya. Pernyataan-pernyataan mengakses hal-hal yang berkaitan dengan; (1) jumlah pesaing yang semakin banyak (IP01); (2) perilaku pesaing yang semakin agresif (IP02); dan (3) loyalitas pengguna jasa kesehatan yang cenderung semakin menurun (IP03). Statistik deskriptif tentang variabel Inten- 
sitas Persaingan disajikan sebagai berikut. Tabel 1 menunjukkan bahwa jawaban responden di atas angka 5 yang berarti menunjukkan kecenderungan intensitas persaingan yang tinggi karena di atas rerata 3.5 (rentang skala $1 \mathrm{sd} 7$ ).

Tabel 1. Intensitas Persaingan

\begin{tabular}{|c|c|c|c|c|}
\hline \multicolumn{5}{|c|}{ Statistics } \\
\hline & & IP01 & IP02 & IP03 \\
\hline \multirow[t]{2}{*}{$\overline{\mathrm{N}}$} & Valid & 39 & 39 & 39 \\
\hline & Missing & 0 & 0 & 0 \\
\hline \multicolumn{2}{|c|}{ Mean } & 5.1795 & 5.1538 & 5.3846 \\
\hline \multicolumn{2}{|c|}{ Std. Deviation } & 1.02268 & 1.06471 & 1.13822 \\
\hline \multicolumn{2}{|c|}{ Minimum } & 3.00 & 3.00 & 3.00 \\
\hline \multicolumn{2}{|c|}{ Maximum } & 6.00 & 7.00 & 7.00 \\
\hline
\end{tabular}

\section{Karakteristik Pelanggan (KP)}

Data variabel Karakteristik Pelanggan (KP) diperoleh dari kuesioner dengan 3 (tiga) butir pernyataan yang menggambarkan proksinya. Pernyataan-pernyataan mengakses hal-hal yang berkaitan dengan: (1) pelanggan yang semakin memiliki informasi tentang penyakitnya (KP01); (2) pelanggan yang semakin tahu tentang bagaimana perkembangan terapi tentang penyakitnya (KP02); dan (3) pelanggan yang semakin menyadari perlunya persyaratan layanan RS berubah di masa mendatang (KP03). Statistik deskriptif tentang variabel Karakteristik Pelanggan disajikan sebagai berikut. Tabel 2 menunjukkan bahwa jawaban responden di atas angka 5 yang berarti menunjukkan kecenderungan karakteristik pelanggan yang semakin canggih karena di atas rerata 3.5 (rentang skala $1 \mathrm{sd} 7$ ).

Tabel 2. Karakteristik Pelanggan

\begin{tabular}{|c|c|c|c|c|}
\hline \multicolumn{5}{|c|}{ Statistics } \\
\hline & & KP01 & KP02 & KP03 \\
\hline \multirow[t]{2}{*}{$\overline{\mathrm{N}}$} & Valid & 39 & 39 & 39 \\
\hline & Missing & 0 & 0 & 0 \\
\hline \multicolumn{2}{|c|}{ Mean } & 6.0000 & 6.0256 & 6.0000 \\
\hline \multicolumn{2}{|c|}{ Std. Deviation } & .45883 & .62774 & .51299 \\
\hline \multicolumn{2}{|c|}{ Minimum } & 5.00 & 5.00 & 5.00 \\
\hline \multicolumn{2}{|c|}{ Maximum } & 7.00 & 7.00 & 7.00 \\
\hline
\end{tabular}

\section{Market-Driven Costing (MDC)}

Data variabel Market-driven Costing (MDC) diperoleh dari kuesioner dengan 3 (tiga) butir pernyataan yang menggambarkan proksinya. Pernyataan-pernyataan mengakses hal-hal yang berkaitan dengan kebeberadaan pengelolaan berbasis harga persaingan, yaitu: (1) tarif rumah sakit pesaing (MDC01); (2) target biaya operasional rumah sakit yang harus ditutup (cost coverage) (MDC02); dan (3) target margin rumah sakit yang harus didapatkan (MDC03).
Statistik deskriptif tentang variabel Marketdriven Costing (MDC) disajikan sebagai berikut. Tabel 3 menunjukkan bahwa jawaban responden di atas angka 5 yang berarti menunjukkan kecenderungan karakteristik pelanggan yang semakin canggih karena di atas rerata 3.5 (rentang skala 1 sd 7).

Tabel 3. Market-driven Costing

\begin{tabular}{lrrrr}
\multicolumn{5}{c}{ Statistics } \\
\hline & MDC01 & MDC02 & MDC03 \\
\hline $\mathrm{N}$ & Valid & 39 & 39 & 39 \\
& Missing & 0 & 0 & 0 \\
Mean & 6.2051 & 6.1026 & 6.2564 \\
Std. Deviation & .69508 & .71800 & .59462 \\
Minimum & 5.00 & 4.00 & 5.00 \\
Maximum & 6.00 & 7.00 & 7.00 \\
\hline
\end{tabular}

\section{Kinerja Keuangan (KK)}

Data variabel Kinerja Keuangan (KK) diperoleh dari kuesioner dengan 3 (tiga) butir pernyataan yang menggambarkan proksinya selama 3 tahun terakhir. Pernyataan-pernyataan mengakses hal-hal yang berkaitan dengan: (1) peningkatan pertumbuhan pendapatan (KK01); (2) peningkatan efisiensi biaya (KK02); dan peningkatan utilisasi aset (KK03). Tabel 4 menunjukkan bahwa jawaban responden di atas angka 5 yang berarti menunjukkan kecenderungan meningkatnya kinerja keuangan karena di atas rerata 3.5 (rentang skala 1 sd 7).

Tabel 4. Kinerja Keuangan (KK)

\begin{tabular}{|c|c|c|c|c|}
\hline \multicolumn{5}{|c|}{ Statistics } \\
\hline & & KK01 & KK02 & KK03 \\
\hline \multirow[t]{2}{*}{$\overline{\mathrm{N}}$} & Valid & 39 & 39 & 39 \\
\hline & Missing & 0 & 0 & 0 \\
\hline \multicolumn{2}{|c|}{ Mean } & 5.4872 & 5.5897 & 5.6923 \\
\hline \multicolumn{2}{|c|}{ Std. Deviation } & 1.09717 & 1.29204 & 1.23871 \\
\hline \multicolumn{2}{|c|}{ Minimum } & 3.00 & 3.00 & 3.00 \\
\hline \multicolumn{2}{|c|}{ Maximum } & 7.00 & 7.00 & 7.00 \\
\hline
\end{tabular}

\section{Pengaruh Langsung Intensitas Persaingan (IP) Terhadap Kinerja Keuangan (KK)}

Hasil olahan pengaruh langsung variabel Intensitas Persaingan (IP) terhadap Kinerja Keuangan (KK) digambarkan pada Gambar 2. Dari gambar tersebut diketahui bahwa Intensitas Persaingan (IP) berpengaruh positif dan signifikan secara statistik terhadap Kinerja Keuangan (KK) dengan nilai estimasi (beta) sebesar 0,54 dan dengan nilai $\mathrm{p}<0,01$. Hal ini dapat diinterpretasikan bahwa 1 variasi deviasi standar Intensitas Persaingan (IP) menyebabkan 0,54 variasi deviasi standar Kinerja Keuangan (KK). Nilai $\mathrm{R}^{2}$ sebesar 0,29 menunjukkan bahwa variansi kinerja keuangan dapat dijelaskan oleh intensitas persaingan sebesar $29 \%$. 




Gambar 2. Pengaruh Langsung IP terhadap KK

Pengaruh Langsung Karakteristik Pelanggan (KP) Terhadap Kinerja Keuangan (KK)

Hasil olahan pengaruh langsung variabel Karakteristik Pelanggan (KP) terhadap Kinerja Keuangan (KK) digambarkan pada Gambar 3. Dari gambar tersebut diketahui bahwa Karakteristik Pelanggan (KP) berpengaruh positif dan signifikan secara statistik terhadap Kinerja Keuangan (KK) dengan nilai estimasi (beta) sebesar 0,58 dan dengan nilai $p<0,01$. Hal ini dapat diinterpretasikan bahwa 1 variasi deviasi standar Karakteristik Pelanggan (KP) menyebabkan 0,58 variasi deviasi standar Kinerja Keuangan (KK). Nilai $R^{2}$ sebesar 0,33 menunjukkan bahwa variansi kinerja keuangan dapat dijelaskan oleh karakteristik pelanggan sebesar $33 \%$.



Gambar 3. Pengaruh Langsung KP terhadap KK

Pengujian Hipotesis 1: Pengaruh Mediasi Market-Driven Costing (MDC) Terhadap Hubungan Intensitas Persaingan (IP) dengan Kinerja Keuangan (KK)

Hasil olahan model penuh atas pengaruh tidak langsung (mediasi) variabel Market-driven Costing (MDC) terhadap hubungan Intensitas Persaingan (IP), Karakteristik Pelanggan (KP) dengan Kinerja Keuangan (KK) digambarkan pada Gambar 4.



Gambar 4. Pengaruh Mediasi MDC terhadap Hubungan IP, KP dengan KK

Berdasarkan Gambar 4 diketahui bahwa koefisien jalur IP-KK hasil estimasi sebesar 0,54. Sementara itu, koefisien jalur IP-KK hasil estimasi full model dengan melibatkan market-driven costing sebagai variabel mediasi sebesar 0,17.
Karena koefisien estimasi jalur IP-KK nilainya turun (dari 0,54 ke 0,17) maka dipastikan terjadi pengaruh mediasi. Untuk melihat bentuk mediasi, maka dilihat tingkat signifikansi pada koefisien estimasi yang semula signifikan pada $\mathrm{p}<0,01$ menjadi tidak signifikan pada $p=0,19$. Hal ini menunjukkan bahwa mediasi market-driven costing tersebut berbentuk mediasi penuh (full mediation). Berdasarkan hal tersebut, maka dapat disimpulkan bahwa hipotesis market-driven costing memediasi penuh hubungan intensitas persaingan dengan kinerja keuangan dapat didukung.

Pengujian Hipotesis 2: Pengaruh Mediasi Market-Driven Costing (MDC) Terhadap Hubungan Karakteristik Pelanggan (KP) Dengan Kinerja Keuangan (KK)

Berdasarkan Gambar 4 diketahui bahwa koefisien jalur KP-KK hasil estimasi sebesar 0,58. Sementara itu, koefisien jalur KP-KK hasil estimasi full model dengan melibatkan marketdriven costing sebagai variabel mediasi sebesar 0,34. Karena koefisien estimasi jalur KP-KK nilainya turun (dari 0,58 ke 0,34) maka dipastikan terjadi pengaruh mediasi. Untuk melihat bentuk mediasi, maka dilihat tingkat signifikansi pada koefisien estimasi yang semula signifikan pada $p<0,01$ menjadi tidak signifikan pada $p=0,19$. Hal ini menunjukkan bahwa mediasi market-driven costing tersebut berbentuk mediasi penuh (full mediation). Berdasarkan hal tersebut, maka dapat disimpulkan bahwa hipotesis market-driven costing memediasi penuh hubungan karakteristik pelanggan dengan kinerja keuangan dapat didukung.

Berdasarkan uraian sebelumnya telah dibuktikan secara empirik bahwa market-driven costing memediasi hubungan intensitas persaingan dengan kinerja keuangan. Semakin tinggi intensitas persaingan antar organisasi rumah sakit di Surabaya, maka semakin meningkat kebutuhan pengelolaan biaya berbasis harga pasar.

Intensitas persaingan yang semakin tinggi memicu manajemen rumah sakit yang sekelas membandingkan tarif mereka dengan tarif pesaing terdekatnya. Hal ini sangat logis karena produk layanan kesehatan yang ditawarkan tidak memiliki pembeda yang jelas. Rumah sakit yang sekelas cenderung memiliki kualitas layanan kesehatan yang nyaris sama sehingga tidak mengherankan bila para pasien memilih rumah sakit yang bertarif murah. Hal ini sesuai dengan yang dinyatakan oleh Porter (1980), bahwa intensitas persaingan sangat berpengaruh ter- 
hadap kinerja profitabilitas organisasi. Dalam Porter's Five Forces, dinyatakan bahwa semakin banyak pemasok akan mengakibatkan posisi tawar (bargaining power of suppliers) menjadi menurun. Semakin banyak pemasok layanan kesehatan mengakibatkan posisi tawar rumah sakit menjadi menurun dalam industri sehingga tidak bisa lagi semaunya menentukan harga layanan. Rumah sakit tidak lagi sebagai (price maker), melainkan harus mengambil harga yang terjadi di pasar (price taker). Pernyataan salah satu informan yang menjabat sebagai direktur keuangan rumah sakit swasta menguatkan hal ini.

"Sekarang ini ... manajemen rumah sakit kalau menentukan tarif ya harus tengok kiri kanan. Kita harus tahu betul berapa tarif layanan kesehatan pesaing-pesaing kita. Banyaknya rumah sakit telah memberikan pasien banyak pilihan. Kalau kita tidak melihat tarif pesaing, ya kita bisa kalah bersaing. Di era persaingan layanan kesehatan seperti sekarang ini, pasarlah yang mendikte kita dalam pentarifan. Kita mau tidak mau harus melihat pasar. Pendapatan kita tergantung harga kita di pasar. Jadi kalau pendapatan kita sudah dipatok pasar ... kuncinya biaya operasional harus dikelola efisien"

Rumah sakit sebagai price-taker membuat manajemen harus semakin berhati-hati dalam mengelola biaya. Tanpa perhitungan biaya dan pengelolaan biaya yang baik, maka product margin akan tergerus dan rumah sakit berpotensi merugi. Market-driven price atau target price harus selalu diikuti oleh market-driven costing agar rumah sakit masih dapat mencapai target margin yang diinginkan. Kebutuhan akan market-driven costing yang akurat ini disadari oleh informan yang menjadi manajer keuangan rumah sakit swasta.

"Kalau kita menentukan tarif layanan berdasarkan tarif pesaing maka sebenarnya harus jelas unit cost kita. Masalahnya perhitungan unit cost di rumah sakit umumnya tidak akurat. Ini bisa berbahaya bagi kelangsungan rumah sakit itu sendiri. Pendapatan kita memang meningkat, tapi apakah kita yakin bahwa kita tidak rugi wong ngitung unit costnya nggak benar. Jadi perhitungan unit cost yang akurat sangat penting perannya, misalnya pakai $A B C^{\prime \prime}$

Dari sisi rivalitas (rivalry among firms), semakin banyaknya penyedia layanan kesehatan akan semakin meningkatnya rivalitas persaingan yang pada akhirnya menurunkan profitabilitas rerata industri seperti yang telah dikemukakan oleh Cool et al. (1995). Dalam dinamika industri layanan kesehatan yang semakin meningkat, memang tindakan dan respons masing-masing organisasi rumah sakit yang sedang bersaing bersifat mutually independent. Hal itu berarti bahwa daya saing, strategi, dan tingkat pengembalian di atas rerata hanya bisa dicapai bila strategi tidak diimplementasi secara terisolasi dengan respon para pesaing seperti yang dikemukakan Baum dan Korn (1999) maupun Henderson dan Mitchell (1997). Organisasi rumah sakit perlu memperhatikan dinamika dan intensitas persaingan dalam industri. Salah satu dokter yang menjadi informan dan sebagai pengelola rumah sakit swasta yang berafiliasi dengan rumah sakit luar negeri menyatakan hal sebagai berikut.

"Dinamika perumahsakitan di Surabaya makin tinggi dari waktu ke waktu. Kita harus mampu memandang jauh ke depan agar bisa bersaing dengan baik. Kalau perlu kita pakai brand luar negeri untuk meningkatkan image rumah sakit. Persaingan yang makin sengit tidak bisa disikapi dengan cara kerja yang biasa seperti dulu. Nggak bakal bisa ... Bakal banyak pendatang baru di bidang layanan kesehatan di Indonesia, khususnya di kota besar seperti Surabaya. Banyak grup-grup perusahaan besar sudah masuk dan berinvestasi besar-besaran di bidang rumah sakit karena dipandang bisa menghasilkan return tinggi"

Market-driven costing yang semakin akurat dan dijalankan dengan baik akan menghasilkan kinerja keuangan yang baik pula. Unit cost yang akurat pada organisasi layanan kesehatan dapat dilakukan dengan memanfaatkan activity-based costing (ABC). Penelitian Kaplan (2011) menunjukkan bahwa kebanyakan rumah sakit tidak mampu menelusuri biaya yang diakibatkan oleh proses-proses administrasi maupun klinis pada masing-masing kondisi pasien sehingga tidak mampu menghitung unit cost yang akurat. Selanjutnya Kaplan menyatakan "with good estimates of the typical path an individual patient takes for a medical condition, providers can use the time-driven activity-based costing (TDABC) system to assign costs accurately and relatively easily to each process step along the path".

Dengan demikian, dapatlah disimpulkan bahwa rumah sakit membutuhkan metode costing yang tepat agar kinerja keuangan semakin baik. Metode costing yang tepat akan memberikan informasi unit cost yang akurat sebagai dasar pengambilan keputusan manajemen, baik dalam 
pemasaran layanan kesehatan maupun pengelolaan operasional layanan kesehatan. Pada akhirnya, hal ini akan memberikan kepuasan kepada pengguna jasa dan memberikan dampak positif terhadap keuangan jangka panjang rumah sakit.

Berdasarkan uraian sebelumnya telah dibuktikan secara empirik bahwa market-driven costing memediasi hubungan karakteristik pelanggan dengan kinerja keuangan. Semakin canggih karakteristik pengguna layanan kesehatan menuntut manajemen berkreativitas lebih tinggi dalam memberikan layanan kesehatan dalam upaya memuaskan pengguna jasa meski dalam rentang harga pasar yang telah ditentukan.

Hasil penelitian ini mendukung pendapat Cooper dan Slagmulder (1995) yang menyatakan bahwa karakteristik pelanggan berdampak pada meningkatnya kebutuhan market-driven costing. Hasil penelitian menunjukkan bahwa pada sektor industri layanan kesehatan di Surabaya terjadi perubahan yang signifikan terhadap karakteristik pelanggan. Perubahan karakteristik pelanggan ini mengakibatkan perubahan atau semakin sempitnya survival zone sebuah produk di bidang layanan kesehatan.

Pertama, perubahan terjadi pada tingkat kecanggihan (sophistication) pengguna jasa layanan kesehatan. Pengguna jasa atau calon pengguna jasa di bidang kesehatan menjadi semakin canggih berkat internet. Saat ini, semua informasi tentang penyakit dan terapinya sudah tersedia di internet. Semakin tinggi tingkat penggunaan internet oleh masyarakat dalam mencari informasi, maka semakin canggih karakteristik pelanggan, tak terkecuali di bidang kesehatan. Situasi tersebut juga dinyatakan oleh salah satu dokter yang menjadi informan.

"Calon pasien maupun pasien sendiri makin hari makin pintar. Semua informasi tentang penyakit sudah ada di Google. Sekarang ini dokter dan perawat tidak bisa lagi sembarangan menjawab pertanyaan pasien atau calon. Tidak seperti dulu, ada gap pengetahuan yang lebar. Sekarang mereka tambah rewel ... ya karena makin pintar. Bila nggak puas dengan jawaban dokter, akan cari di internet atau minta keluarga atau temannya nyarikan. Tak jarang ada pasien yang berdebat panjang dengan dokter soal penyakitnya. Dokter yang tidak mau memberikan informasi detil pada pasien dianggap dokter kuno dan bagian dari masa lalu"

Tingkat kecanggihan pengguna layanan kesehatan di Surabaya akan menentukan seberapa baik mereka mendeteksi perbedaan-perbedaan harga, kualitas, dan fungsi dari beragam produk layanan kesehatan yang bersaing. Semakin tinggi kecanggihan pengguna langgan maka pelanggan semakin mampu menentukan perbedaan-perbedaan kecil yang selanjutnya semakin mudah beralih ke produk layanan kesehatan yang ditawarkan oleh para pesaing. Semakin canggih pelanggan akan mengakibatkan survival zone suatu produk layanan kesehatan menjadi semakin sempit dan berdampak pada kegagalan suatu produk layanan kesehatan yang diluncurkan di luar zona tersebut. Di sinilah manajemen organisasi rumah sakit perlu melakukan analisis pengguna layanan kesehatan secara lebih mendalam, khususnya menentukan lokasi survival zone tersebut dan konsekuensi biaya yang ditimbulkan. Hal senada dinyatakan oleh dokter yang menjadi informan sebagai berikut.

"Calon pasien yang makin canggih memungkinkan manajemen rumah sakit berkreasi dalam menawarkan variasi produk kesehatan yang ditawarkan. Rumah sakit asing bahkan membundling layanan berobat dengan paket pariwisata, seperti rumah sakit di Malaysia atau Singapura. Manajemen sekarang memang harus kreatif. Kreativitas itupun menimbulkan biaya yang terkadang tidak murah. Memang harus pandai-pandai membidik pasarnya pada siapa"

Kedua, perubahan terjadi pada tingkat pengetahuan pengguna layanan kesehatan di Surabaya terhadap persyaratan produk rumah sakit yang perlu diubah di masa mendatang. Internet telah memberikan informasi rinci tentang beragam terapi penyakit dan memungkinkan calon atau pengguna layanan kesehatan untuk melakukan benchmark antar produk-produk yang ditawarkan. Hal ini memungkinkan mereka mengetahui seberapa tingkat kualitas layanan rumah sakit yang satu dibanding dengan rumah sakit lainnya. Mereka mengetahui seberapa tinggi kualitas layanan sebuah rumah sakit dalam menangani terapi penyakit mereka. Dengan demikian mereka mengetahui pula bahwa persyaratan layanan kesehatan sebuah rumah sakit harus diubah di masa mendatang, seperti dikemukakan oleh dokter yang menjadi informan sebagai berikut.

"Banyaknya informasi terapi penyakit di dunia maya membuat pasien mudah membandingkan. Memang demikian jamannya. Website rumah sakit yang baik berisi macammacam keunggulan produknya. Misalnya pasien penyakit jantung koroner. Pasienpasien itu tahu kalau di rumah sakit $A$ itu canggih ... di rumah sakit B sudah kuno. 
Jadi mereka bisa dengan gampang menentukan kalau kualitas layanan rumah sakit $B$ perlu improvement di masa mendatang. Ya ujung-ujungnya kan perlu investasi dan biaya".

Ketiga, perubahan terjadi pada kebutuhan masa depan atas terapi penyakit. Era informasi telah mengakibatkan para pengguna jasa memiliki pengetahuan tentang apa yang dibutuhkan untuk menangani penyakitnya. Semakin tinggi pengetahuan pelanggan terhadap kebutuhan masa depan, maka semakin bermanfaat bagi manajemen rumah sakit memercayai preferensi pengguna layanan kesehatan dalam menentukan lokasi survival zone tersebut. Hal ini akan memudahkan dalam merancang dan mengelola biaya berbasis pasar. Salah satu pengelola rumah sakit bedah mengungkapkan hal berikut.

"Kalau semua informasi terapi penyakit sudah lengkap di internet ... maka pasienpasien itu tahu apa yang mereka butuhkan. Ya memang ada pasien yang tak mau tahu. Tapi kebanyakan pasien atau keluarganya tahu apa yang menjadi kebutuhan mereka mendatang ... dan itu yang diharapkan mereka dari sebuah produk layanan kesehatan di rumah sakit pilihan mereka"

Berdasarkan uraian sebelumnya, maka tidaklah mengherankan bila secara empirik terbukti bahwa market-driven costing memediasi hubungan karakteristik pelanggan dengan kinerja keuangan. Semakin canggih karakteristik pengguna layanan kesehatan menuntut manajemen berkreativitas lebih tinggi dalam layanan kesehatan dalam upaya memuaskan pengguna jasa. Hal ini akan berdampak pada biaya-biaya yang harus dikelola sebagai konsekuensinya maupun kinerja keuangan lainnya.

\section{KESIMPULAN DAN SARAN}

Dari hasil penelitian ini dapat disimpulkan hal-hal sebagai berikut:

(1) Market-driven costing memediasi hubungan antara intensitas persaingan dengan kinerja keuangan pada rumah sakit di Surabaya. Semakin tinggi intensitas persaingan antar organisasi rumah sakit di Surabaya, maka semakin meningkat kebutuhan pengelolaan biaya berbasis harga pasar. Hal ini selanjutnya berdampak pada kinerja keuangan rumah sakit, khususnya kinerja pengelolaan biaya maupun pendapatan rumah sakit.

(2) Market-driven costing memediasi hubungan karakteristik pelanggan dengan kinerja keuangan rumah sakit di Surabaya. Semakin tinggi karakteristik pengguna layanan kesehatan berkat informasi internet menuntut manajemen berkreativitas lebih tinggi dalam memberikan layanan kesehatan untuk memuaskan pengguna jasa dalam rentang harga pasar yang telah ditentukan. Hal ini memicu kebutuhan pengelolaan biaya yang semakin baik dan berorientasi pelanggan

Dari hasil penelitian ini dapat disarankan hal-hal sebagai berikut:

(1) Manajemen rumah sakit di Surabaya perlu meningkatkan kualitas manajemen biaya berbasis pasar market-driven costing yang dipicu oleh intensitas persaingan. Penetapan tarif berbasis harga pesaing tanpa diikuti manajemen biaya yang baik dan akurat berpotensi merugikan kelangsungan hidup rumah sakit. Metode perhitungan biaya yang memberikan informasi yang lebih akurat, seperti activitybased costing layak dipertimbangkan untuk diimplementasikan guna mendukung marketdriven costing yang baik.

(2) Manajemen rumah sakit di Surabaya perlu meningkatkan kualitas manajemen biaya berbasis pasar market-driven costing yang dipicu oleh karakteristik pelanggan. Pemahaman manajemen rumah sakit terhadap tingkat kecanggihan pelanggan (degree of customer sophistication), tingkat perubahan persyaratan (rate of change of requirements), dan pengetahuan tentang kebutuhan di masa depan (knowledge of future requirements) atas produk layanan kesehatan perlu diperdalam melalui riset pelanggan secara berkesinambungan.

Penelitian ini terbatas pada area di Surabaya sehingga daya generalisasinya juga untuk wilayah Surabaya saja. Penelitian berikutnya dapat diperluas pada area Jawa Timur atau bahkan di Indonesia. Penelitian ini juga terbatas menggunakan media kuesioner untuk memperoleh data primer sehingga bertumpu pada tataran persepsi responden atau informan sehingga faktor subyektivitas bisa saja terkandung di dalamnya. Penelitian berikutnya dapat menggunakan media selain kuesioner atau interview, seperti menggunakan data sekunder atau serangkaian pendapat ahli, misalnya Delphi method.

\section{DAFTAR PUSTAKA}

Baum, J. A. C. \& Korn, H. J. (1999). Dynamics of Dyadic Competition, Strategic Management Journal, 251 - 278.

Cool, K., Binberd, B. L., Young, M.N., \& Toss L. K. (1995). The Relative Impact of Actual and Potential Rivalry on Firm Profitability in the 
Pharmaceutical Industry, Strategic Management Journal 20,1-14.

Cooper, R. \& Slagmulder, R. (1997). Factors Influencing the Target Costing Process: Lessons from Japanese Practice. Unpublished Research.

Cooper, R. \& Tanaka, T. (1996). Toyota Motor Corporation, Harvard Business School Case.

Gatignon, H. (1984). Competition as Moderator of the Effect of Advertising on Sales. Journal of Marketing Research, 21 (November), 387-398.

Henderson, C. R. \& Mitchell, W. (1997). The Interactions of Organizational and Competitive Influences and Strategy and Performance. Strategy Management Journal, 18, Special Summer Issue, 5-14.

Kaplan, R. S. \& Norton, D. P. (2004). Strategy Maps: Converting Intangible Assets into Tangible Outcomes. Boston MA: Harvard Business Review Press.

Miles, M. B. \& Huberman, A. M. (1992). Analisis Data Kualitatif: Buku Sumber Tentang Metode-metode Baru. Terjemahan Tjetjep Rohendi Rohidi. Jakarta: UI Press.
Mowen, M. M., Hansen, D. R., \& Heitger, D. L. (2014). Cornerstones of Managerial Accounting. Fifth Edition. Singapore: South-Western.

Porter, M. E. (1980). Competitive Strategy: Techniques for Analyzing Industries and Competitors. New York: The Free Press.

Porter, M. E. and Kaplan, R. S. (2011). How to Solve The Cost Crisis In Health Care. Harvard Business Review, 4: 47-64.

Sholihin, M. \& Ratmono, D. (2013). Analisis SEMPLS dengan Warp PLS untuk Hubungan Non Linier dalam Penelitian Sosial dan Bisnis. Yogyakarta: Penerbit Andi.

Weitz, B. A., Sujan, H., \& Sujan, M. (1986). Knowledge, Motivation, and Adaptive Behavior: A Framework for Improving Selling Effectiveness, Journal of Marketing, 50, 174-191.

www.bloomberg.com/visual-data/best-and-worst/ most-efficient-health-care-countries, Most Efficient Health Care. Diakses 12 Maret 2014 jam 11:35.

www.who.int/about/definition/en/print.html. Diakses 12 Maret 2014 jam 11:43 